\title{
The role of human capital on family firm innovativeness: the strategic leadership role of family board members
}

\section{Andrea Calabrò $^{1}$ • Mariateresa Torchia ${ }^{2}$ - Daniela Gimenez Jimenez ${ }^{3}$. Sascha Kraus ${ }^{4}$}

Published online: 23 April 2020

(C) The Author(s) 2020

\begin{abstract}
Drawing on the resource-based view of the firm, this study investigates the relationship between human capital (employees' experience, knowledge and technical skills, managerial talent) and innovativeness (propensity to innovate) in a sample of 478 family firms taken from a cross-country dataset (STEP Project). Furthermore, we consider the moderating effect of the proportion of family members sitting on the board of directors (family board ratio). The main findings highlight that there is a positive relationship between human capital and family firm innovativeness. Moreover, family board ratio positively moderates the relationship between human capital and innovativeness in such a way that when the family board ratio is high, the relationship between human capital and innovativeness is stronger. This result is weaker when multiple family generations are actively involved in the firm. In summary, family members sitting on the board of directors focus more attention on people and for this reason, play an important strategic leadership role in valorizing human capital that fosters more innovativeness.
\end{abstract}

Keywords Family firms · Human capital · Innovativeness · Board of directors · Generations · STEP Project

Sascha Kraus

sascha.kraus@zfke.de

Andrea Calabrò

a.calabro@ipag.fr

Mariateresa Torchia

mtorchia@inseec.com

Daniela Gimenez Jimenez

daniela.gimenez@tum.de

Extended author information available on the last page of the article 


\section{Introduction}

Innovation is the establishment of new concepts, procedures and/or technologies in an organization (Kraus et al. 2012). Recently, there has been increasing research interest in innovation in family firms (hereafter FFs) (e.g., Chrisman et al. 2015; Llach et al. 2012; De Massis et al. 2015; Calabrò et al. 2019). This is due to an increasing awareness of the role of innovation in fostering FFs' competitive advantage (Rößl et al. 2010). However, current research has generated mixed results, emphasizing the need for further research (Calabrò et al. 2019; Chrisman et al. 2015; Filser et al. 2016). Moreover, our body of knowledge on innovation in non-family firms (NFFs) cannot be imported into the FF context since FFs have unique features that differentiate them from NFFs (Craig et al. 2014; Gomez-Mejia et al. 2011).

It is widely recognized that familiness is a distinctive feature of FFs (e.g., Arregle et al. 2007; Pearson et al. 2008; Schulze et al. 2003). Indeed, because of their strong socioemotional ties to their firms, founders prioritize maintaining control of their firm. They therefore attempt to influence ownership, management and governance of their firm, mainly by using younger generations (Berrone et al. 2012; Calabrò et al. 2018; Gómez-Mejía et al. 2007; Cesinger et al. 2016). In turn, familiness, i.e., "resources and capabilities related to family involvement and interactions" (Chrisman et al. 2004) create advantages as well as disadvantages for FFs (Habbershon and Williams 1999). Indeed, recent reviews on innovation in FFs demonstrate that family involvement in ownership/management influences innovation inputs, outcomes and activities (Calabrò et al. 2019; Chrisman et al. 2015). However, so far we know very little about how family involvement in boards may affect innovation in FFs.

Applying the resource-based perspective (Barney 1991; Habbershon and Williams 1999; Habbershon et al. 2003) and considering familiness, we first investigate the association between FFs human capital and FFs innovativeness.

Employees' experience, knowledge, technical skills and talent can reflect the firm's human capital (Hitt et al. 2001). Among other resources, such as social and financial capital, (De Massis et al. 2015), we focus on human capital for two main reasons. First, according to the resource-based view (RBV), knowledge is the most critical competitive asset that a firm possesses and this resides in human capital (Grant 1996; Hitt et al. 2001). Second, more research is called for to better understand the link between FFs' resources and their innovativeness (Calabrò et al. 2019). Innovativeness can be defined as the set of activities through which a firm conceives, designs, manufactures and introduces a new product, service or process (Burgelman et al. 1988). The lack of research on innovativeness in FFs is interesting as some studies have demonstrated its importance for FFs (Covin et al. 2016).

According to the RBV, a firm's resources are key to its survival, but resources must also be managed effectively (e.g., through an appropriate strategy) to produce value (Barney and Arikan 2001). Strategic leadership in managing resources (human capital) is an important contingency factor surrounding the effects of FFs' human capital (Hitt et al. 2001; Sirmon and Hitt 2003; Sirmon et al. 2007). Effective implementation of such strategic leadership requires the formation of social capital among members (top executives) of the group that will take on the role. Social capital refers to the goodwill and resources made available to an individual and organization via reciprocal, trusting relationships 
that facilitate action and create value (Adler and Kwon 2002; Hitt et al. 2002; Maran et al. 2019). Theory emphasizes that familiness may lead to the formation of internal social capital (Arregle et al. 2007; Pearson et al. 2008). In turn, the formation of internal social capital might lead to certain FF capabilities, namely efficient exchange of information, tacit knowledge and adaptation of shared action and goals (Pearson et al. 2008). From this perspective, increasing family involvement in FF boards might contribute to the formation of internal social capital, enrich the relevant information and shared perspectives, and lead to better management of human capital (Sirmon et al. 2007). We argue that boards of FFs can play a strategic leadership role in managing resources. By benefiting from the capabilities of their social capital, family board members can facilitate the coordination of activities and projects across various functional units. This will enable effective decision-making by the board as well as implement the resulting decisions. Developing and managing resources may contribute to the development of the innovative capacity of FFs (Eddleston et al. 2008).

Furthermore, we recognize that increasing family involvement might result in increasing the presence of subsequent and multiple generations on FF boards (Habbershon and Williams 1999). While heterogeneity created by family and nonfamily managers is theoretically well-recognized in social capital theory (Arregle et al. 2007; Pearson et al. 2008), it is assumed that internal social capital is formed by a homogenous group of family members.

Subsequent generations may have different economic motives (short-run vs longterm) and status-related and power-related expectation of the FF. This can lead to competition, rivalry, envy and political behaviour among subsequent and multiple generations (Davis and Harveston 1991; Gersick et al. 1997; Lubatkin et al. 2005). It is likely that family members on boards representing multiple generations may experience substantial conflict during the formulation of strategic decisions that may affect control and ownership of the FF (Bammens et al. 2008; Kellermanns and Eddleston 2004; Eddleston and Kellermanns 2007). Such high levels of conflict might affect the boards' strategic leadership by negatively influencing 1) the formation of internal social capital (Pearson et al. 2008) and 2) the utilization of FFs' capabilities (Sirmon et al. 2007). From this board-level perspective, having multiple generations can be detrimental to the successful deployment of board strategic leadership through the management of FFs' human capital. Indeed, boards of multigenerational FFs could have power games, conflict and negative emotions among family directors. Such boardroom dynamics may hinder a board's successful implementation of their strategic leadership in managing resources and in turn limit the firm's innovativeness.

Our work contributes to the growing body of literature on FF innovation and Transgenerational Entrepreneurship in FFs. While previous studies have mainly explored whether family involvement in ownership and management affects innovation (Calabrò et al. 2019; Filser et al. 2018), the role that boards play in this relationship is underexplored (Chrisman et al. 2015). This study is the first to explain the leadership role of boards on FFs' innovativeness. We introduce the RBV as a novel theoretical perspective to provide a conceptual path for examining the way in which a distinctive feature of FFs, familiness, may lead to heterogeneous performance outcomes and also explain how the family survives across time by keeping alive their entrepreneurial spirit and mindset from one generation to the other. 


\section{Theory development and hypotheses}

\section{The relationship between human capital and FFs' innovativeness: A resource-based view approach}

The unique features of FFs have been widely debated in the family business research field. However, the "so what?" questions that tended to surface when unique features of FFs were discussed (Habbershon and Williams 1999), have recently started to be addressed in FF research. The RBV (Barney 1991, 2001) has been used as a theoretical perspective to explain whether the uniqueness of FFs may lead to certain advantages and disadvantages. This special bundle of resources may in turn explain performance differences between FFs and NFFs (Arregle et al. 2007; Basco et al. 2019a; De Massis et al. 2015; Habbershon and Williams 1999; Pearson et al. 2008; Salvato and Melin 2008; Sirmon and Hitt 2003). This study places familiness at its centre in examining the link between human capital and innovativeness in FFs as well as the moderation effect of board strategic leadership in managing resources.

According to the RBV, returns achieved by firms are largely attributable to their resources (Barney 1991). The resources a firm possesses are used to generate capabilities and those capabilities result in a competitive advantage for the firm that in turn leads to better firm performance (Habbershon and Williams 1999). The RBV considers knowledge as the most critical competitive asset that a firm possesses and it resides in human capital (Grant 1996; Hitt et al. 2001). Knowledge can be articulable and tacit (Lane and Lubatkin 1998). Articulable knowledge can be written and easily transferred because it is partially embedded in individual skills and partially embedded in collaborative working relationships within the firm. On the other hand, tacit knowledge is often unique and difficult to imitate and therefore has a higher probability of creating strategic value (Lane and Lubatkin 1998). Professionals gain knowledge through formal education (articulable) and through learning on the job (tacit). Accordingly, much of an organization's knowledge (articulable and tacit) resides in its human capital.

Research into NFF contexts suggests that human capital attributes (e.g., education, skills and experience) affect a firm's outcomes. For instance, employees with higher education may contribute to business development, innovation and R\&D investments. Moreover, board research in a NFF context emphasizes the positive link between human capital (board) and strategic decisions. However, the distinctive features of FFs means that these NFF results cannot be transferred to the FF context (Sirmon and Hitt 2003). Recent calls for research stress the importance of understanding the link between FFs' resources and innovativeness (Calabrò et al. 2019).

An FF is defined as a public or private company in which a family (or related families) controls the largest block of shares or votes, has one or more of its members in a key management position, and members of more than one generation are actively involved within the business (Miller and Le Breton-Miller 2005, p. 2). Based on this definition, a common feature of FFs is the relevant involvement of controlling family members in ownership, management as well as governance (e.g., board membership), shaping both strategic and daily activities. Family members' involvement in both business and family relationships in their personal and professional lives may create advantages as well as disadvantages with respect to resources (Arregle et al. 2007; Habbershon and Williams 1999; Pearson et al. 2008; Sirmon and Hitt 2003). 
Familiness is used as an umbrella concept referring to outcomes relating to family involvement and interactions (Chrisman et al. 2004; Habbershon and Williams 1999 Basco et al, 2019a, Basco et al, 2019b).

Family control and influence may have both positive and negative effects on FFs' human capital. Positive effects can be explained through certain conditions created on the stock of human capital (Gómez-Mejía et al. 2007). FFs pursue non-financial goals such as creating and maintaining trust-based, long-term relationships with firm-internal stakeholders (e.g., employees, managers) (Berrone et al. 2012). Due to such relationships, FFs' human capital can be thought to have positive attributes like commitment to business, motivation, firm-specific tacit-knowledge. For instance, De Massis et al. (2015) have emphasized that higher motivation, cohesiveness and commitment in FFs may enable FFs to "mitigate the drawbacks that characterize the use of functional organizations (e.g., communication problems, conflicts between the functional heads) and to manage the complexity of product innovation projects..." (p. 14). Moreover, the characteristics of a member of a FF (employees, managers) create strong identification with the firm and motivation to collectively pursue goals. This enables innovation activities to be administered with a high level of decision autonomy (De Massis et al. 2015).

On the other hand, the goal of control and influence can lead FFs to rely exclusively on family members. This can lead to a shortage of qualified personnel (Karra et al. 2006). The dark side of altruism may even result in hiring and promoting more and more family members beyond their capabilities (Schulze et al. 2003). Moreover, qualified managers may avoid FFs due certain barriers (e.g., exclusive succession, limitations on wealth transfer). In addition, unfair human resource management practices may reduce employees' incentive to invest in firm-specific knowledge (Miller et al. 2008).

Research on the relationship between FFs' human capital and FFs' innovation is scarce (Calabrò et al. 2019). We are aware of only one study which rejects the idea that FFs cannot attract and retain qualified employees (Llach and Nordqvist 2010). Llach and Nordqvist (2010) indicate that FFs have a stronger human capital base to enhance innovation than NFFs. Moreover, Salvato and Melin (2008) indicate that it might not be the access to resources that causes problems for FFs, but the social interactions between family members in management. Chrisman et al. (2015) emphasize that a FF's decision to innovate or not may be related to willingness, family control and influence, rather than ability and access to critical resources. In addition, several studies indicate that when FFs are willing to innovate, they can be more innovative than NFFs (Calabrò et al. 2019; Chrisman et al. 2015).

Building up long-term, trust-based relationships with employees and managers may have a positive impact on FFs' human capital (Miller and Le Breton-Miller 2005). Due to these relationships, tenure appears to be substantially longer in FFs than NFFs (Lansberg 1999), leading to high levels of experience as well as firm-specific tacit knowledge. Long tenure provides managers and employees with experience and deep tacit knowledge of the business, clients, markets and technologies. This knowledge can help them to continually introduce incremental improvements to their products and processes. Employees and managers with higher firm specific tacit knowledge and technical skills, as well as managerial talents, can be expected to positively influence innovation in FFs (Nordqvist 2005). High levels of human capital within a firm are 
beneficial within the innovation process (Hadjimanolis 2000) since "a firm's innovative performance is at least partially a function of the value of its human capital" (Rothaermel and Hess 2007, p. 899). The interaction of experienced and skilled employees leads to further accumulation of tacit knowledge, which in turn fosters the development of new technologies (Dosi 1982). Employees are a potentially important source of creativity and innovation in organizations. Informal interactions between employees are good facilitators of tacit-knowledge utilization. The innovation process can be facilitated by interactions and by the effective sharing of tacit knowledge (Koskinen and Vanharanta 2002).

We therefore expect that the high level of commitment and tacit knowledge among employees (Sirmon and Hitt 2003) in FFs will foster the transfer of valuable ideas across hierarchies and departments (Bammens et al. 2015). This will contribute to the introduction of new products, services and processes. Thus, we formulate:

Hypothesis 1: There is a positive relationship between human capital and FFs' innovativeness.

\section{Board strategic leadership to manage FFs' resources}

Several FF scholars have emphasized the importance of exploring the contingency effects associated with the understanding of RBV in the context of FFs by keeping in mind that resources need to be strategically deployed and leveraged (Chrisman et al. 2003; Habbershon and Williams 1999; Sirmon and Hitt 2003). Sirmon et al. (2007) also support this view and note that "heterogeneity in firm outcomes under similar initial conditions may result from choices made in the structuring, bundling, and leveraging of resources" (p. 275).

Human capital is a FF's repository of valuable knowledge and skills with certain attributes (e.g., tacit knowledge, commitment, motivation due to familiness). However, fully benefiting from this important resource requires strategic management (Sirmon and Hitt 2003). Strategic leadership helps firms assess how resources should be allocated for greater innovation and risk-taking (Thomke and Kuemmerle 2002). For example, research into FFs demonstrates that strategic planning of innovation processes by top management teams has positive effects on innovative capacity (Eddleston et al. 2008) and corporate entrepreneurship (Kellersmans and Eddleston 2006). Corporate entrepreneurship refers to the entrepreneurial activities within an organization that are designed to revitalize the company's business by changing its competitive profile or by emphasizing innovation (Zahra 1995; Ferreira et al. 2019).

We argue that boards of FFs can play a strategic leadership role in managing FF resources. Strategic leadership in managing resources is composed of four actions: evaluating and changing resource stocks, configuring and leveraging resources (Sirmon et al. 2007). The first step is evaluating current human capital and making necessary changes. Effective strategic leaders should know the skills and capabilities of the people with whom they work. It is equally important to identify whether those employees have the ability to learn and develop new capabilities. These two evaluations can be key in assigning a job to the right person. If qualified people are scarce, the initiative must be taken in order to change human capital resources (bringing in new employees or managers). Once human capital resources are secured, configuring begins which can be seen as the leaders' coordination in matching task requirements to 
employees' skills and capabilities. The last step involves leveraging activities of qualified employees who are assigned to particular work groups to accomplish certain tasks and goals. To this end, a strategic leader (a manager of the R\&D team) should manage group activities by providing the direction, facilitation and empowerment to enable group members to realize their potential.

However, to display such an important role at the group level, strategic leaders need to have the required social capital. Social capital is the goodwill and resources made available to an individual and organization via reciprocal, trusting relationships that facilitate action and create value (Adler and Kwon 2002; Hitt et al. 2002). While internal-social capital involves the relationships between individuals or groups working in the organization, external social capital involves relationships between the organization and external parties (Adler and Kwon 2002).

Formation of internal social capital, (social capital formed by family members in FFs), can be as critical an aspect of strategic leadership as managing resources (Sirmon et al. 2007). Familiness might turn internal social capital into a resource which is valuable, rare, costly to imitate and without substitutes (Arregle et al. 2007; Salvato and Melin 2008). Thus, familiness, a distinctive feature of FFs, can turn strategic leadership of boards of FFs into a competitive advantage. This explains how FFs are different from other organizational forms.

Formation of internal social capital requires some conditions. This leads to the accumulation of capabilities such as access to efficient information and exchange, accumulation of social capital and collective actions that might benefit FFs. Stability and time, closer interdependence and interaction are conditions that lead to structural aspects (e.g., network ties), relational aspects (e.g., trust, norms, obligation), and cognitive aspects (e.g., shared vision and goals) of internal social capital.

Social capital is built on lasting investments in social relationships (Bourdieu, 1986) and requires a significant amount of time to develop and grow (Coleman 1988). Continuity in social structures increases the clarity and visibility of mutual obligations (Misztal 1996), as well as the development of trust and norms of cooperation (Hitt et al. 2002). The long-term goals of the family are survival of the business and control over the firm. These help to build the lasting relationships and stability necessary to generate social capital (Arregle et al. 2007).

Developing and protecting social capital requires substantial mutual interdependence (Nahapiet and Ghoshal 1998). Conversely, when individuals are less dependent upon one another, social capital erodes (Coleman, 1988). Interdependence is largely a function of joint and shared interests and an agreement toward shared goals (Gersick et al. 1997). As mentioned before, the founders' goal of keeping control of family business within the family is likely to result in family members being appointed to key managerial positions. While family managers may need to get advice from the founders when managing the firm, they often possess task-department-market related tacit knowledge which is key in making critical decisions. Leana III and Van Buren (1999) argue that for social capital to contribute to organizational capabilities of collective action, it has to be jointly owned by interdependent actions of members.

Interaction is required to develop and maintain social capital (Adler and Kwon 2002). Indeed, "while interdependence shapes the degree to which vision and goals are developed and shared among group members, interaction reflects the quantity, quality, and strength of those relationships among group members. Social ties and relationships 
tend to be strengthened with interaction and weakened without it" (Arregle et al. 2007, p. 962). Family members, may continue to interact and facilitate ties and relationships during working hours, performing overlapping roles as manager and board member. These interactions may produce more social capital as actors have the opportunity to get to know each other, share important information and create a common point of view (Tsai and Ghoshal 1998).

Finally, closure may lead to the development of social capital (Nahapiet and Ghoshal 1998). In fact, it "can be interpreted loosely as the degree to which boundaries exist, which prevent external influences and enhance internal focus on such management activities as information sharing and decision making" (Arregle et al. 2007, p.961). For example, the possibility of opportunistic behaviour within a social group is minimized by a high density of ties among members and the accompanying threat of group sanctions against violators (Portes 1998, p. 6). It facilitates the development of trust, norms, identity (Coleman, 1988; Ibarra, 1992), and unique codes or language (Boland and Tenkasi, 1995). Arregle et al. (2007) argue that closure is particularly strong in FFs. In turn, internal social capital may generate certain capabilities. The capabilities derived from internal social capital are identified as efficient access to information, tacit knowledge, professional experience as well as collective action in accomplishment of shared goals (Arregle et al. 2007). Internal social capital may contribute to innovation by motivating the cooperation, communication and coordination among different members in a firm (Adler and Kwon 2002; Nahapiet and Ghoshal 1998). Research demonstrates that internal social capital is positively associated to FFs' innovativeness (Sanchez-Famosa et al. 2014). We argue that these capabilities may contribute to successful implementation of strategic leadership in managing FFs resources (Sirmon et al. 2007). Therefore, family involvement in boards can provide important leadership advantages that are unlikely occur in boards of NFFs.

\section{Moderating effects of board strategic leadership: Increasing family involvement in boards}

Because of the strong socioemotional ties to their firms, founders attempt to introduce children to the business at a young age, gear their education toward the business, create succession plans based on promoting family members, keep the founder or older generations active in the firm, and keep ownership within bloodlines (Birley et al. 1999; Calabrò et al. 2018). Such ties also shape FFs' board composition, such that boards are dominated by family members of different generations (Basco et al. 2019; Voordeckers et al. 2007). Moreover, familiness means that "role overlap" is common in FFs (Anderson and Reeb 2004). From this perspective, a family board member and manager may possess firm-department related tacit knowledge and develop social relationships with employees. These together may help him/her to evaluate employees' skills and capabilities, assign them to the right tasks and facilitate group activities to achieve goals. Hence, a family board member can be more effective than a non-family board member in evaluating and changing resource stocks and configuring and leveraging resources.

However, it is possible that no single family board member has all the information on the bundle of human capital. As family board members share a common goal (introducing new products and services) each may individually share information about 
the existing human capital stock and together evaluate whether qualified employees or talented managers are available in the FF to achieve the shared goal. Because of familiness, family directors may influence how the available human capital is bundled and leveraged (Sirmon et al. 2007). Benefiting from family directors' social capital can facilitate the coordination of activities and projects across various functional units, increase the effectiveness of board decision-making processes and support the implementation of decisions (Hitt et al. 2002). Developing and managing resources may contribute to building FFs' innovative capacity which has been shown to be positively related to performance (Eddleston et al. 2008). Therefore, an increasing number of family directors may enrich the pool of relevant information and perspectives within the board as well as the stock of available firm-related tacit knowledge. Furthermore, such boards display a stronger strategic leadership in managing and leveraging FFs' human capital which fosters the generation and transfer of valuable ideas across hierarchies and departments (Bammens et al. 2015). Thus, we hypothesize that:

Hypothesis 2: The relationship between human capital and FFs' innovativeness is moderated by the family board ratio in such a way that the relationship is stronger with increasing levels of family board ratio.

\section{The moderating effect of board strategic leadership: The influence of multi-generations}

Previous studies of FFs have recognized the heterogeneity embedded in such organizations where family members bring internal social capital and non-family members are seen as an important source of external social capital (Arregle et al. 2007). However, the inherent heterogeneity within the group of family members has been neglected so far by assuming that family members form a homogeneous group (Santulli et al. 2019). We argue that decision-making dynamics, in particular within the board, could change if we consider family firms that have varying degrees of generational involvement within the firm. Indeed, the formation of internal social capital might change if the FF has only one generation actively involved in the business in comparison to those with multiple generations actively involved.

RBV scholars have highlighted the importance of managing resources over the possession of resources as well as the importance of interpersonal relationships and interactions between managers (e.g., Kor and Mahoney 2004). Earlier, we have argued and hypothesized the positive effects of increasing family involvement in boards. We believe that such increases, together with the increasing involvement of multiple generations, can be an important factor in influencing the effect of the previously hypothesized positive moderation.

Previous research has emphasized that different generations might differ in relation to motives driving strategic actions, firm-specific tacit knowledge and understanding of ownership (Gersick et al. 1997; Eddleston et al. 2013; Torchia et al. 2018).

When members of subsequent generations are appointed to boards even those individuals may lack tacit knowledge, information, or experience that may contribute to configuring and leveraging resources in increasing innovation. The dark side of altruism may even result in hiring and promoting an increasing numbers of family members beyond their capabilities (Blumentritt et al. 2007; Schulze et al. 2003). A lack 
of firm-related tacit knowledge is especially pronounced when there are multiple generations all actively involved in the business. They will belong to different family tribes which may not have previously been involved in the operative life of the firm (Santulli et al. 2019). Thus, in comparison to FFs that have only one generation actively involved in the firm, those characterized by having members from multiple generations often experience long, and sometimes very critical, discussions during the formulation of strategic decisions that could affect the future of the FF. Such increasing presence of family members from multiple generations may also bring detrimental effects of passive family shareholders (Jaffe and Lane 2004) who tend to prefer short-term dividend pay-outs as opposed to long-term performance (Schulze et al. 2003; Bammens et al. 2008). While FFs with only one generation involved in the firm may be more willing to focus on long-term investments (e.g., on innovation) for the survival of the family firm, FFs with multiple generations involved may have different sub-goals related to their respective family tribes (Calabrò et al. 2017; Santulli et al. 2019), and thus be more interested in pursuing short-term economic returns. This often means investing less in high growth projects such as innovation activities. In addition, if a large number of family members from different generations are involved in a FF, envy may increase political behaviour leading to frequent arguments over money, managerial roles and ownership (Davis and Harveston 1998). Therefore, multigenerational FFs can result in "substantial conflict" (Kellermanns and Eddleston 2004, p. 209).

Conflict increases as "brothers and sisters, aunts and uncles, cousins and in-laws argue about money, managerial roles, ownership and control, and the future direction of the family business" (Davis and Harveston 1999, p. 319). In turn, intense and frequent disagreements may adversely affect interpersonal relationships (Kellermanns and Eddleston 2004). Such relationships are vital for formation of internal social capital as well as sharing of information and tacit knowledge and collective action toward shared goals. Such high levels of conflict may easily trigger relational conflict (Kellermanns and Eddleston 2004, 2006). Previous studies have shown that in FFs there is a higher risk that task conflicts are misperceived as personal attacks which escalates the animosity and personal conflict (Kellermanns and Eddleston 2007). Relational conflict is associated with resentment, animosity, anger, frustration and hostile behaviour (Jehn 1995).

Emerging relational conflict can distract and deflect attention away from the important tasks, severely limiting the ability of board members to share unique information and knowledge and/or communicate individual perspectives (e.g., Jehn et al. 1999). The board members may become preoccupied with feelings of anger, frustration and resentment (Filbeck and Smith 1997). Previous studies suggest that conflict in FFs has a detrimental effect, particularly during critical decisions. Some studies suggest that knowing the cost of high inner-family conflict may produce a negative association between family involvement in ownership and investments in R\&D (e.g., Calabrò et al. 2019). Bammens et al. (2008) indicate the negative effects of subsequent generations on board tasks through their positive impact on the level of conflict among family members. Kellermanns and Eddleston (2006) suggest that while strategic planning heightened corporate entrepreneurship in one generation, it did not have a positive effect on multigenerational FFs.

The structural, cognitive and relational components of internal social capital can be negatively affected by the presence of multigenerational FF boards. Different motives, 
orientations, ownership and authority, have the potential to cause disagreements among members from different generations. Resultant feelings of anger, frustration and resentment may easily harm the interaction, closure, interdependence and time-stability. For example, a clear adverse impact will be on interdependence as it shapes the degree to which vision and goals are developed and shared among board members. Interaction is important in developing and maintaining social capital (Adler and Kwon 2002; Arregle et al. 2007, p.962), reflecting the quantity, quality and strength of relationships among group members. FFs with members from different generations may experience detrimental effects due to potential relational conflict. As a result, it is not possible to fully build cognitive, structural and relational aspects of internal social capital with the associated benefits (capabilities).

In addition to such adverse effects on the formation of internal social capital, having members from different generations on boards may also reveal negative consequences regarding the utilization of capabilities resulting from existing internal social capital. Despite the valuable and unique internal social capital that can be built by founders, multiple generations may negatively affect the efficient exchange of information, tacit knowledge and the pursuit of collective action to accomplish goals. In fact, conflict may distract family members from their work, deflect attention away from core tasks toward resolution of the conflict.

To summarize, if increasing family involvement on boards reflects an increasing number of generations on the board, leadership can be hindered due to the adverse effects of having multiple generations involved in the formation of internal social capital as well as the utilization of FFs' capabilities. Thus, in multigenerational FFs the strategic leadership of boards in managing FFs human capital might be constrained and thus reduce the degree of firm innovativeness. Drawing from these arguments, we formulate:

Hypothesis 3: The relationship between human capital and FFs' innovativeness is moderated by the family board ratio, in such a way that the relationship is stronger at increasing levels of the family board ratio, unless FFs have multigenerational involvement.

\section{Methods}

\section{Data collection and sample}

We used data from the Successful Transgenerational Entrepreneurship Practices Project (STEP Project). ${ }^{1}$ The STEP project collected data from September 2014 to February 2015 from 35 countries. Data were collected by the universities affiliated with the STEP project around the world. The STEP project examines how families generate new economic activity through venturing, renewal and generation. The STEP Consortium, integrated by 48 institutions when the fieldwork was carried out, hired the services of the Survey Research Institute at Cornell University to conduct the online survey. The STEP project selected FFs fulfilling the following criteria: (i) a family should hold the largest or dominant block of voting shares of the firm, (ii) the family firms should be at least in the second generation, (iii) the family business should be among the most important players in the industry that it

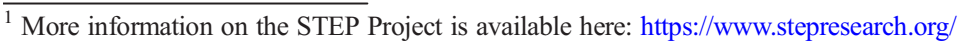


operates in. An experienced research team that had carried out qualitative research into transgenerational FFs for more than 10 years created the STEP questionnaire based on previously validated scales. A pilot test of the survey instrument was conducted between 20 June and 30 July, 2014. The results of the pilot test were used to introduce modifications to the questionnaire in order to obtain the final survey instrument. The survey was generated in English and offered in 12 languages (Spanish, German, Simplified and Traditional Chinese, Dutch, Thai, Swedish, Russian, Italian, Brazilian Portuguese, French and Japanese). In all cases, a professional translation service was used. The survey consisted of four blocks: general information, respondent information, family business group level (performance dimensions), and primary company level (entrepreneurial orientation, family resources, family involvement, family life cycle stages, business environment, and industry).

The STEP project used a multi-respondent methodology. Two members from each participating FF answered the same survey. This methodology was used to assess the FF's successful transgenerational practices in Europe, Latin America, Asia, North America and Africa. 1056 individuals belonging to 686 FFs responded the questionnaire. The response rate was $27 \%$ (STEP 2015). We use data from the respondents who said that the family holds $50 \%$ or more voting rights of at least one firm, thus giving us a usable sample of 478 FFs from 25 countries (Australia, Belgium, Canada, Chile, China, Colombia, Dominican Republic, France, Germany, Hong Kong, Ireland, Italy, Japan, Malaysia, Mexico, Netherlands, Peru, Puerto Rico, Russia, Spain, Sweden, Switzerland, Taiwan, United Kingdom, United States and Venezuela).

The average firm age was 57.62 (Std. Dv=0.918) years old, and 862.882 is the average number of full-time employees. Since the average sales are 12,3, this represents average sales of $\$ 45$ million to $\$ 50$ million. On average $66.40 \%$ of seats of the board of directors are held by family members. In addition to this, $45.39 \%$ of the FFs are held by one generation only, and $52.92 \%$ of the survey respondents stated that the FF is multigenerational.

In addition, we tested for common method variance (Podsakoff et al. 2003), using several techniques. First, the respondents were guaranteed that their answers would remain anonymous. Second, the questionnaire was crafted to avoid desirability bias by soliciting perceptual information with no right or wrong answer. Moreover, to preclude respondent fatigue, the questionnaire designers avoided common scale formats, and predictor and criterion variables were not measured in proximity. Fourth, we tested the Harman (1976) single-factor to check for common method bias. We entered all the selfreported measures into a principal component analysis with varimax rotation. The single-factor solution indicated that one factor explained only $18.87 \%$ of the variance. Finally, we conducted a common latent factor for our confirmatory factor analysis (Podsakoff et al. 2003; Podsakoff et al. 2012), using structural equation modelling. The results of the single-factor structure had a poor fit (chi2 $=613.782, p<0.000$; RMSEA $=0.125, \mathrm{p}<0.000, \mathrm{CFI}=0.525$; $\mathrm{SRMR}=0.108$ ), thus providing assurance that common method biases are not a concern. 


\section{Variables}

\section{Dependent variable}

FFs' innovativeness The questions on innovativeness were developed by the STEP and are based on psychometric scales (Richard et al. 2004). We used three items from the STEP survey with responses on a Likert scale ranging from 1 (minor changes/lines in the last five years) to 5 (many changes/lines in the last five years). The items are: "Is very seldom the first firm to introduce new products/services, technologies, etc.", "Has not introduced any new lines of products or services in the last five years" and "Has introduced only minor changes in products or services in the last five years". Cronbach's alpha was 0.78 and the $\mathrm{KMO}=0.69$, well above the minimum threshold set for reliability (Nunnally 1967). We computed an average of these items to obtain our dependent variable. These items are consistent with previous studies of innovativeness in FFs (Richard et al. 2004).

\section{Independent variables}

Human capital We operationalized human capital using data from the STEP project. We used four items in which the FFs were asked if they possess any of the following resources: "experienced employees," "knowledgeable employees," "technical ability of employees" and "access to managerial talent." Each of the items was ranked using a five-point Likert scale ranging from 1 (not at all) to 5 (a great deal). Cronbach's alpha was 0.87 and the $\mathrm{KMO}=0.81$, well above the minimum threshold set for reliability (Nunnally 1967). We created an average of these items to obtain our independent variable. Several scholars have observed that there is a relationship between human capital and innovativeness in NFFs (Hatch and Dyer 2004) as well as in family businesses (e.g., De Massis et al. 2015; Classen et al. 2014). Additional information is shown in Appendix 1.

\section{Moderating variable}

Family board ratio To test the hypothesized interaction effect, we followed previous studies (Anderson and Reeb 2004; Jaskiewicz and Klein 2007). In a similar way to Anderson and Reed (2004) we developed family board ratio using the number of seats held by family members divided by the total seats of the board. The average ratio is 0.664 , suggesting that $66.40 \%$ of the board seats are held by family members.

Generation involvement The STEP survey asked the respondents whether the FF had one generation or multiple generations actively involved in the firm (Davis and Harveston 1998; Cruz and Nordqvist 2012; Sonfield and Lussier 2004). This was operationalized as a dummy variable in which 1 represents only one generation of the family actively involved in the FF and 0 represents at least two generations (i.e., multiple generations) are actively involved. 
Control variables We followed previous literature to control for firm age and number of employees (numeric variables) (e.g., Classen et al. 2014; Diéguez-Soto et al. 2016). The number of employees is a logarithmic transformation of the number of employees in the firm. We also controlled for growth of market share (numeric variable and fivepoint Likert scale variable), intense competition (five-point Likert scale variable), industry risk (numeric variable and five-point Likert scale variable), the importance of physical assets (numeric variable and a four-point Likert scale), unique technology (numeric variable and five-point Likert scale), sales (numeric variable, using intervals of 31 respondents that provide the average sales in US dollars in 2013), changes take place continuously (numeric variable and five-point Likert scale variable), products change fast (numeric variable and five-point Likert scale variable) and strong competitors (numeric variable and five-point Likert scale variable). Finally, we included industry as a control (categorical variable in which $1=$ information, technology and communication, 2 = trade, $3=$ consulting, $4=$ advertising and marketing, 5 = education and training, $6=$ tourism and gastronomy, $7=$ health services, $8=$ other services, $9=$ architecture and engineering, $10=$ construction and manufacturing, $11=$ others). The selection of these control variables was based on previous literature on innovativeness (Hall et al. 2009) and innovativeness in FFs (Classen et al. 2014). Appendix 2 provides a summary of all the variables. The descriptive statistics and pairwise correlation of all variables included in the regression estimation are shown in Table 1.

\section{Statistical procedure}

Our dependent variable is a numeric variable (innovativeness), therefore we specified an OLS with robust standard errors using the STATA 13.0. Prior to specifying the regression, we ran the correlation matrix and tested for multicollinearity. We acknowledge that there is a high correlation between sales and number of employees as well as strong competitors and intense competition. Nevertheless, the highest variance inflation factor (VIF) among the independent variables was 2.85 which is well below that of the conservative cut-off value of 5.0 (Studenmund 1992). Therefore, multicollinearity was not a concern in this study.

In the first step of the robust regression analysis, we added only the control variables (Model 1). In the second step we included human capital as the independent variable (Model 2), and in the third step, we included the moderating effect of family board ratio (Model 3). We then created a subsample in which we observed whether one generation was actively involved in the FF (Model 4) vs multigenerational involvement (Model 5).

\section{Results}

Table 2 shows the results of the robust regression estimation.

The results for the control variables confirmed some of our expectations (Model 1). First, there is a positive and statically significant effect of the number of employees on FFs' innovativeness. With respect to the growth in the market share, having unique technology and facing continuous market changes has a positive and statistically significant effect on FFs' innovativeness. The next step of analysis was to test the 


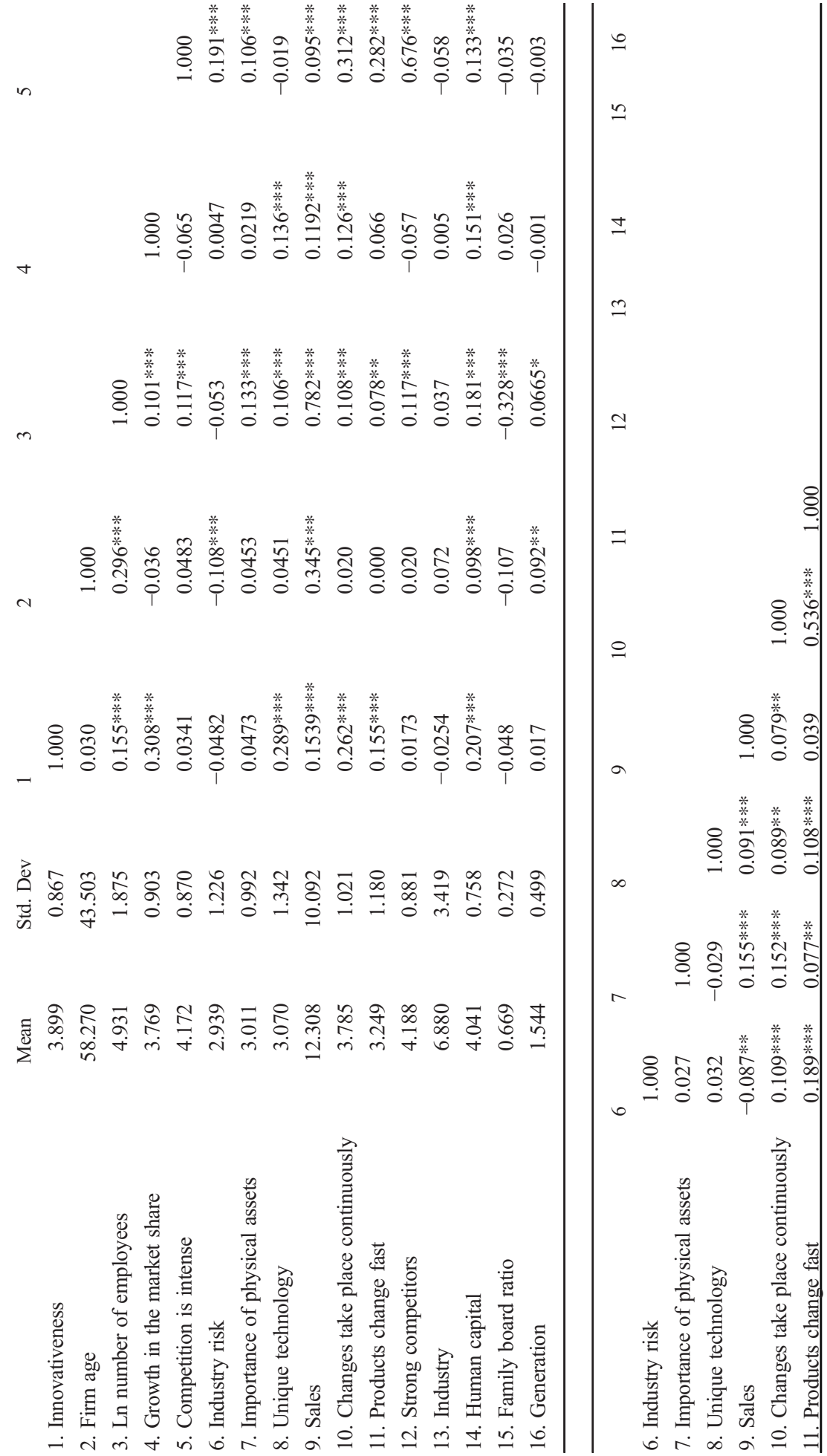




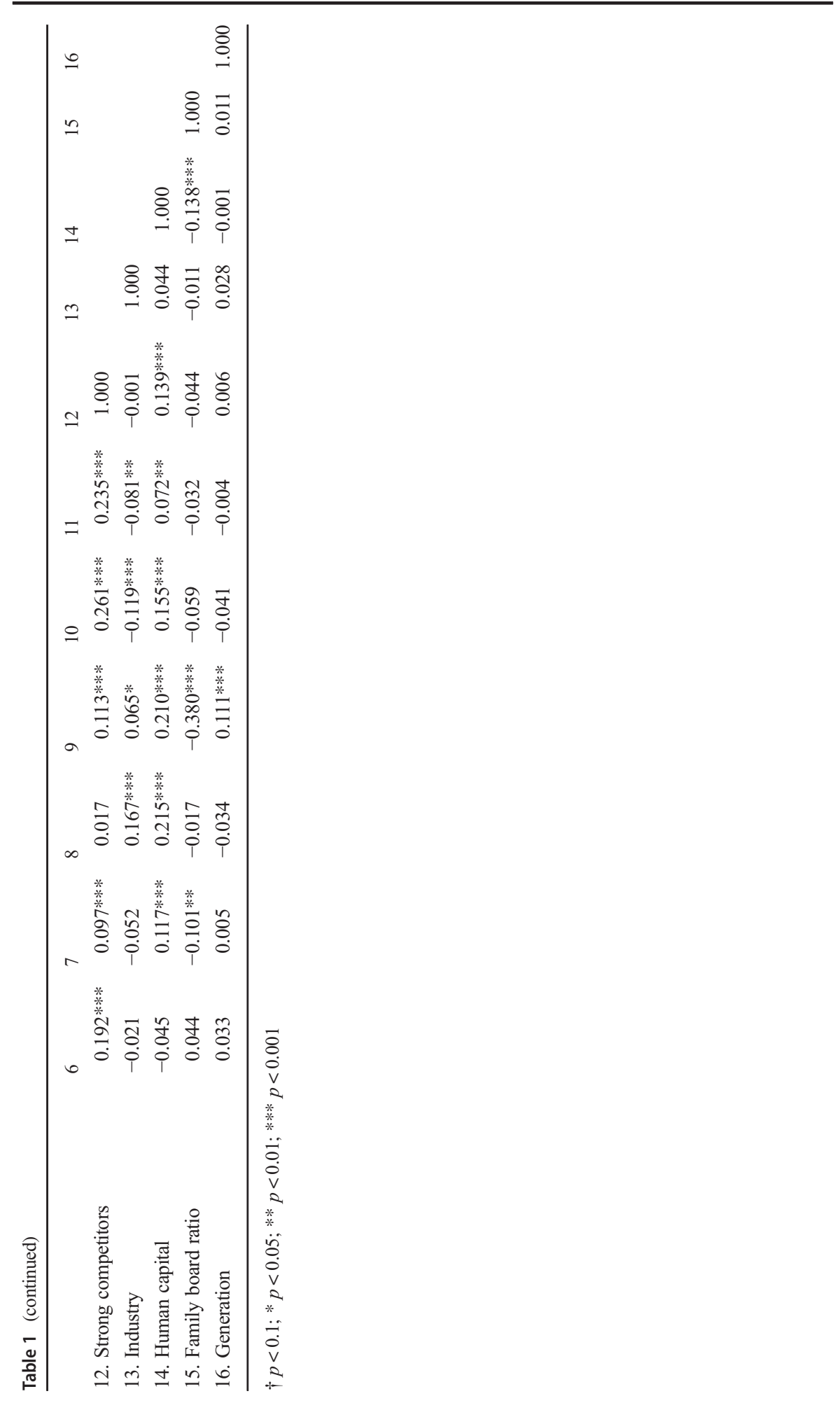

\section{型 Springer}




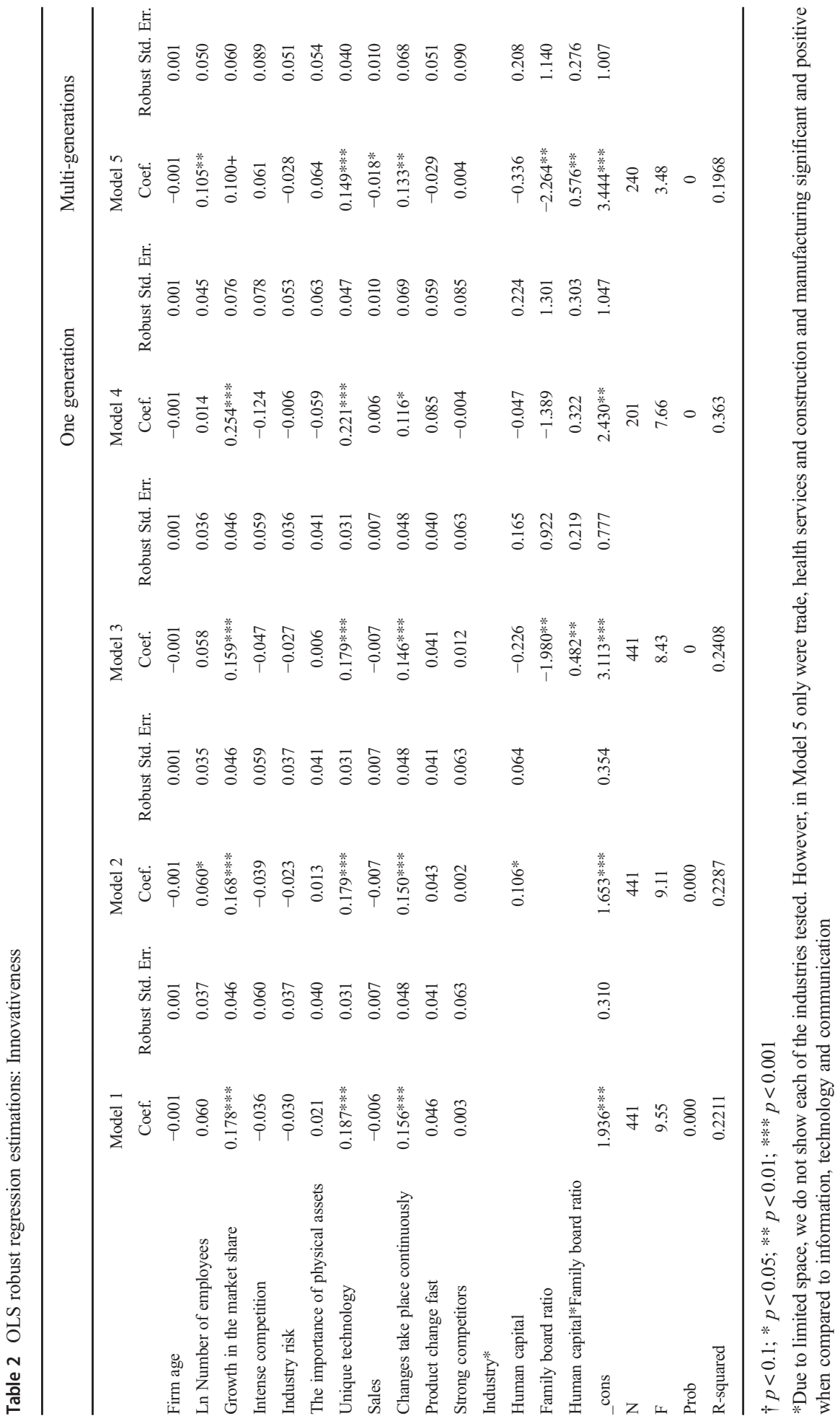


main effects of human capital (Model 2). The relationship between human capital and FFs' innovativeness is positive and statistically significant $(\beta=0.106, p<0.1)$. Thus, hypothesis 1 was supported. Model 3 shows the interaction between human capital and family board ratio. The result shows that the interaction effect between human capital and family board ratio is statistically significant $(\beta=0.482, p<0.05)$ namely, the relationship between human capital and innovativeness is stronger when there is a high family board ratio. Thus, hypothesis 2 was supported. In Model 4, we tested the interaction effect between human capital and family board ratio in the firms in which only one generation is involved. The results show that in these FFs, the interaction between human capital and family board ratio does not have a statistically significant effect on FF's innovativeness $(\beta=0.219$, n.s). In Model 5, when multiple generations are involved in the FF, the interaction effect between human capital and family board ratio is statistically significant $(\beta=0.579, p<0.05)$. Therefore, hypothesis 3 is supported. Compared to Model 1, the inclusion of the interaction leads to an increase of the adjusted R-squared value from $22.11 \%$ to $36.30 \%$ in Model 4 and $19.68 \%$ in Model 5. Visual representations are provided in Figs. 1 and 2.

\section{Robustness tests}

To test the robustness of our results, we conducted additional analyses. We use a structural equation model (SEM) to test the robustness of our model. However, we first transformed our moderating variable into a categorical variable, in which 1 represents a low percentage of family members on the board of directors ( 0 to $40 \%$ ), 2 represents a medium percentage of family members on the board of directors (41 to $80 \%$ ), and 3 represents a high percentage of family members on the board of directors (81 to 100\%). Second, our independent and dependent variables were turned into latent variables using the same items. Figures 3 and 4 show the results of our SEM analyses. These are similar to the results of our main analyses. We observe that when only one generation is involved, the relationship between human capital and FFs' innovativeness is not moderated by the percentage of family members on the board of directors. However, this situation is slightly different when there is a high percentage of

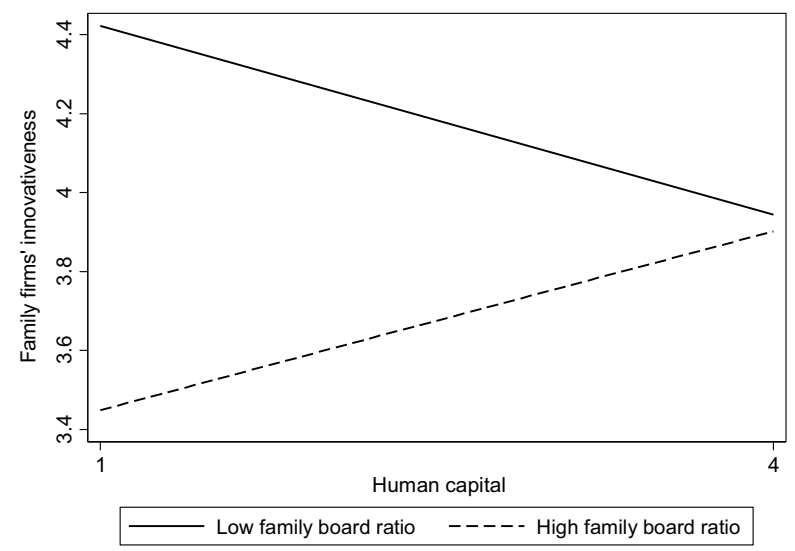

Fig. 1 Interaction between human capital and family board ratio: All FFs 


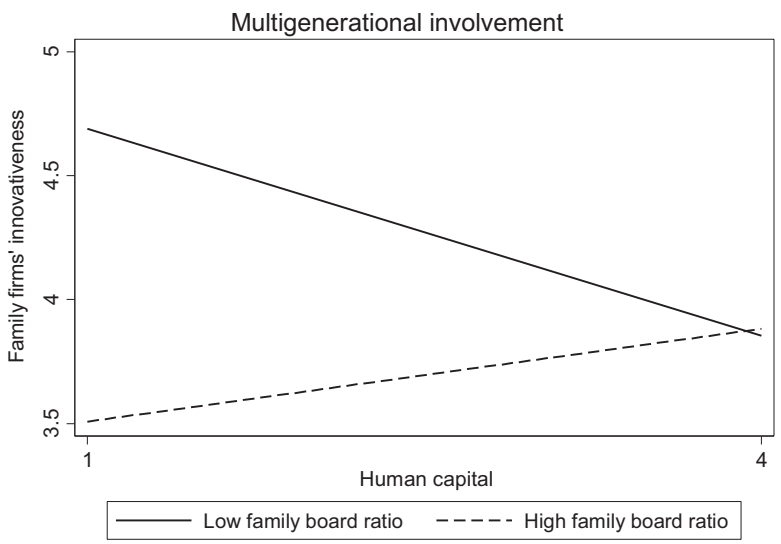

Fig. 2 Interaction between human capital and family board ratio: Multigenerational FFs

family members on the board, the results show that it has a positive effect on the relationship between human capital and FFs' innovativeness. On the other hand, the results show that when there is multigenerational involvement in the FF and a low percentage of family members on the board of directors, the relationship between human capital and FFs' innovativeness is negative and statistically significant. On the contrary, when there is a medium or high percentage of family members on the board, the relationship between human capital and FFs' innovativeness is positive and statistically significant. We also deleted the variables sales and competition intensity. Finally, we ran our analysis using a bootstrapping approach and our findings did not change; the interaction effect of human capital and family board ratio occurs in FFs in which there is a multigenerational involvement (these results are available upon request from the authors). Therefore, we proved that the model is reliable. These results support our main findings and show the positive influence of family members in the relationship between human capital and FFs' innovativeness, especially when there is active multigenerational involvement.

\section{Discussion and conclusion}

Drawing on the RBV of the firm, the aim of this study was to investigate the relationship between human capital (employees' experience, knowledge and technical skills, as well as managerial talent) and innovativeness (propensity to innovate) in a sample of 478 FFs (from 25 countries). Additionally, this study investigated this relationship in more depth by considering the moderating

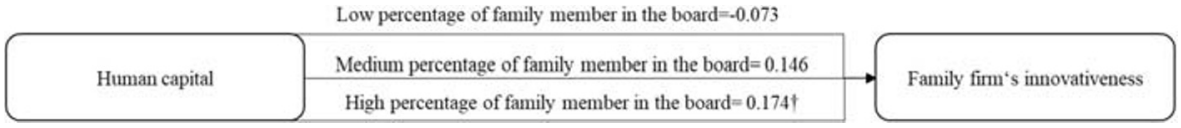

Fig. 3 Results of the SEM analysis for the involvement of only one generation Note: The model includes all the control variables and was estimated using STATA's SEM command. Estimation Method Maximum Likelihood; Log likelihood $=-9026.468, N=248$, the coefficients are standardized. $* p<0.10$; $* * p<0.05$; $* * * p<0.001$ 


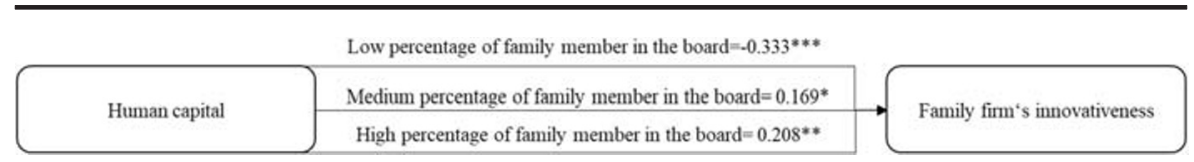

Fig. 4 Results of the SEM analysis for multigenerational involvement Note: The model includes all the control variables and was estimated using STATA's SEM command. Estimation Method Maximum Likelihood; Log likelihood $=-10,632.244, N=288$, the coefficients are standardized. $* p<0.10 ; * * p<0.05$; *** $p<0.001$

effect of the proportion of family members sitting on boards (family board ratio).

In line with previous studies, we found that employees represent an important source of creativity and innovation for organizations. Interaction among employees is a facilitator of utilization of tacit knowledge and the innovation process is positively affected by an effective use of tacit knowledge (Koskinen and Vanharanta 2002). However, contrary to the general expectation and previous studies that emphasize a negative relation between family involvement and innovation (Kor 2006), we found that increasing family involvement in boards had a positive effect on innovativeness. Indeed, while family board ratio is generally considered to hinder innovation, pushing FFs to hire outsider board members, we posit a contrary explanation. Because of the high emotional attachment that they have to the firm, family board members may possess firm-related tacit knowledge and develop social relationships with employees that facilitate the achievement of goals. Specifically, family board members are more effective than non-family members in the accumulation and use of tacit knowledge with a positive effect on innovativeness.

Additionally, we highlight the need to adopt a more fine-grained analysis of increasing family involvement. We suggest that in multigenerational FFs the relationship between the family board ratio and human capital and the FFs' innovativeness is weaker. This finding contradicts previous studies that indicate positive effects of subsequent generations on innovative activities (e.g., Salvato 2004). In the light of these findings, we enter the "ability and willingness" debate. Our work supports the idea that founders' desire to control and influence their firms (willingness), rather than FFs' access to resources (ability), may be key in better understanding and explaining FFs' innovation behaviour (Chrisman et al. 2015). We draw the attention of FFs scholars to contingencies (Chrisman et al. 2015; Corbetta and Salvato 2004) as well as a more fine-grained analysis of constructs (multi-generations) which may better explain the mixed results on innovation in FFs (Calabrò et al. 2019).

This study contributes to literature on social capital in FFs (Arregle et al. 2007; Pearson et al. 2008). Our findings are in line with previous studies that emphasize the importance of strategic leadership in better utilizing FFs' resources (Sirmon and Hitt 2003; Salvato and Melin 2008; Sirmon et al. 2007). Moreover, we enrich the literature on social capital by challenging the assumption adopted in previous studies that family members create a homogenous group (Arregle et al. 2007; Pearson et al. 2008). Instead, we introduce issues related to heterogeneity among family board members as an important factor that affects the formation of inter-social capital and the use of its capabilities. 
Lastly, we believe our study has important practical implications. We suggest that corporate leaders of FFs should limit the involvement of members from multiple generations in boards as multigenerational boards may act as a barrier to innovativeness. Furthermore, if this is an inevitable reflection of their concerns related to socioemotional wealth, it would be better to have certain strategies in place to address management conflict (Kellermans and Eddleston 2006). Increasing family involvement in boards may explain why FFs display different innovation behaviour to NFFs. Moreover, the presence of multiple generations may explain why FFs do not equally benefit from the impact of boards on FFs' innovativeness.

\section{Appendix 1. Factor analysis}

\begin{tabular}{|c|c|c|c|}
\hline Components & Items & F.L & Source \\
\hline \multirow[t]{3}{*}{$\begin{array}{l}\text { Family firms' } \\
\text { innovativeness } \\
\text { (Cronbach's } \\
\text { alpha }=0.784)\end{array}$} & $\begin{array}{l}\text { Please select the choice that best describes the } \\
\text { strategy of Primary company: Is very seldom } \\
\text { the first firm to introduce new } \\
\text { products/services, technologies, etc. }\end{array}$ & 0.861 & \multirow[t]{3}{*}{$\begin{array}{l}\text { Successful } \\
\text { Transgenerational } \\
\text { Entrepreneurship } \\
\text { Practices }\end{array}$} \\
\hline & $\begin{array}{l}\text { Please select the choice that best describes the } \\
\text { strategy of Primary company: Has not } \\
\text { introduced any/many new lines of products } \\
\text { or services in the last five years }\end{array}$ & 0.846 & \\
\hline & $\begin{array}{l}\text { Please select the choice that best describes the } \\
\text { strategy of Primary company: Has introduced } \\
\text { only minor/dramatic changes in products or } \\
\text { services in the last five years }\end{array}$ & 0.795 & \\
\hline \multirow[t]{4}{*}{$\begin{array}{l}\text { Human capital } \\
\text { (Cronbach's } \\
\text { alpha }=0.873)\end{array}$} & $\begin{array}{l}\text { Please indicate the extent to which your Family } \\
\text { Business Group possesses each of the } \\
\text { following resources: Experienced employees }\end{array}$ & 0.887 & \multirow{4}{*}{$\begin{array}{l}\text { Successful } \\
\text { Transgenerational } \\
\text { Entrepreneurship } \\
\text { Practices }\end{array}$} \\
\hline & $\begin{array}{l}\text { Please indicate the extent to which your Family } \\
\text { Business Group possesses each of the } \\
\text { following resources: Knowledgeable } \\
\text { employees }\end{array}$ & 0.905 & \\
\hline & $\begin{array}{l}\text { Please indicate the extent to which your Family } \\
\text { Business Group possesses each of the } \\
\text { following resources: Technical ability of } \\
\text { employees }\end{array}$ & 0.867 & \\
\hline & $\begin{array}{l}\text { Please indicate the extent to which your Family } \\
\text { Business Group possesses each of the } \\
\text { following resources: Access to managerial } \\
\text { talent }\end{array}$ & 0.787 & \\
\hline
\end{tabular}




\section{Appendix 2. Variable description}

\begin{tabular}{|c|c|}
\hline Variable & Description \\
\hline $\begin{array}{l}\text { Family firm } \\
\text { innovativeness }\end{array}$ & $\begin{array}{l}\text { A numeric variable, used three items, collected using a five-point Likert-scale } \\
\text { ( } 1=\text { strongly disagree and } 5=\text { strongly agree). In these questions, respondents } \\
\text { could choose the best description of their firms. The options were as follows: } \\
1 \text { = Is very seldom the first firm to introduce new products/services, technologies, } \\
\text { etc. } \\
5 \text { = Is very often the first firm to introduce new products/services, technologies, } \\
\text { etc. } \\
1=\text { Has not introduced any new lines of products or services in the last five years } \\
5=\text { Has introduced many new lines of products or services in the last five years } \\
1=\text { Has introduced only minor changes in products or services in the last five } \\
\text { years } \\
5 \text { = Has introduced quite dramatic changes in products or services in the last five } \\
\text { years }\end{array}$ \\
\hline Human capital & $\begin{array}{l}\text { A numeric variable, used four items, collected using a five-point Likert-scale } \\
\quad(1=\text { strongly disagree and } 5=\text { strongly agree). In these questions, respondents } \\
\text { could choose the best description of their firms. The options were as follows: } \\
\text { Experienced employees } \\
\text { Knowledgeable employees } \\
\text { Technical ability of employees } \\
\text { Access to managerial talent }\end{array}$ \\
\hline Board of directors & $\begin{array}{l}\text { A categorical variable which captures the percentage of seats held by the family } \\
\text { on the board of directors. 1 = Low percentage of family on the board of } \\
\text { directors }(0-40 \%) \\
2=\text { Medium percentage of family on the board of directors }(41-80 \%) \\
3=\text { High percentage of family on the board of directors }(81-100 \%)\end{array}$ \\
\hline
\end{tabular}

Generation involvement A dummy variable which captures the generational involvement in the family firm:

$1=$ Only one generation is actively involved in the family firm

$0=$ At least two generations are actively involved in the family firm

Firm age

Number of employees

Growth of the market share

Intense competition

Industry risk

Importance of physical assets

Unique technology
A numeric variable which capture the number of years that the firm that has been active

A numeric variable which captures the number of employees in the firm (logarithmic transformation)

A numeric variable which captures how they perceive the growth of the market share with respect to their competitors in the last three years $(2011,2012,2013)$ (five-point Likert-scale in which $1=$ strongly disagree and $5=$ strongly agree).

Competition in our market is intense (five-point Likert-scale in which $1=$ strongly disagree and $5=$ strongly agree).

A numeric variable that captures the industry perception. The highest point represents the perception that the industry is very risky, such that one bad decision could easily threaten the viability of the company (five-point Likert-scale in which $1=$ strongly disagree and $5=$ strongly agree).

A numeric variable to rank the importance of physical assets for the firm's competitive advantage ( $1=$ most important, $4=$ least important $)$. 


\begin{tabular}{|c|c|}
\hline Variable & Description \\
\hline & $\begin{array}{l}\text { A numeric variable which captures the extent to which unique technology is } \\
\text { important as a resource }(1=\text { not at all, } 5=\text { a great deal). }\end{array}$ \\
\hline Sales & $\begin{array}{l}\text { A numeric variable capturing the sales in } 2013 \text { (US dollars). This variable has } 31 \\
\text { values }(1=500.000 \$ \text { or less, } 31=500.000 .000 \$ \text { or more sales })\end{array}$ \\
\hline $\begin{array}{l}\text { Changes take place } \\
\text { continuously }\end{array}$ & $\begin{array}{l}\text { In our market, changes are taking place continuously (five-point Likert-scale in } \\
\text { which } 1=\text { strongly disagree and } 5=\text { strongly agree). }\end{array}$ \\
\hline Products change fast & $\begin{array}{l}\text { A numeric variable that captures how the market is perceived. The respondents } \\
\text { answer whether the volumes of products and services to be delivered change } \\
\text { fast and often (five-point Likert-scale in which } 1=\text { strongly disagree and } 5= \\
\text { strongly agree). }\end{array}$ \\
\hline Strong competitors & $\begin{array}{l}\text { A numeric variable that captures how respondents perceive themselves with } \\
\text { respect to their competitors. The respondents answer to the following statement } \\
\text { "our company has relatively strong competitors" (five-point Likert-scale in } \\
\text { which } 1=\text { strongly disagree and } 5=\text { strongly agree). }\end{array}$ \\
\hline Industry & $\begin{array}{l}\text { A categorical variable which captures the industry in which the firm is located } \\
\text { ( } 1=\text { information, technology and communication, } 2=\text { trade, } 3=\text { consulting, } \\
4=\text { advertising and marketing, } 5=\text { education and training, } 6=\text { tourism and } \\
\text { gastronomy, } 7=\text { health services, } 8=\text { other services, } 9=\text { architecture and } \\
\text { engineering, } 10=\text { construction and manufacturing, } 11=\text { others). }\end{array}$ \\
\hline
\end{tabular}

Open Access This article is licensed under a Creative Commons Attribution 4.0 International License, which permits use, sharing, adaptation, distribution and reproduction in any medium or format, as long as you give appropriate credit to the original author(s) and the source, provide a link to the Creative Commons licence, and indicate if changes were made. The images or other third party material in this article are included in the article's Creative Commons licence, unless indicated otherwise in a credit line to the material. If material is not included in the article's Creative Commons licence and your intended use is not permitted by statutory regulation or exceeds the permitted use, you will need to obtain permission directly from the copyright holder. To view a copy of this licence, visit http://creativecommons.org/licenses/by/4.0/.

\section{References}

Adler, P. S., \& Kwon, S. W. (2002). Social capital: Prospects for a new concept. Academy of Management Review, 27(1), 17-40.

Anderson, R. C., \& Reeb, D. M. (2004). Board composition: Balancing family influence in S\&P 500 firms. Administrative Science Quarterly, 49(2), 209-237.

Arregle, J. L., Hitt, M. A., Sirmon, D. G., \& Very, P. (2007). The development of organizational social capital: Attributes of family firms. Journal of Management Studies, 44(1), 73-95.

Bammens, Y., Voordeckers, W., \& Van Gils, A. (2008). Boards of directors in family firms: A generational perspective. Small Business Economics, 31(2), 163-180.

Bammens, Y., Notelaers, G., \& Van Gils, A. (2015). Implications of family business employment for employees' innovative work involvement. Family Business Review, 28(2), 123-144.

Barney, J. B. (1991). Firm resources and sustained competitive advantage. Journal of Management, 17(1), 99-120.

Barney, J. B. (2001). Resource-based theories of competitive advantage: A ten-year retrospective on the resource-based view. Journal of Management, 27(6), 643-650.

J. B Barney, A. M Arikan (2001). The resource-based view: Origins and implications. The Blackwell handbook of strategic management, 124-188.

Basco, R., Campopiano, G., Calabrò, A., \& Kraus, S. (2019a). They are not all the same! Investigating the effect of executive versus non-executive family board members on firm performance. Journal of Small Business Management, 57(2), 637-657. 
Basco, R., Calabrò, A., \& Campopiano, G. (2019b). Transgenerational entrepreneurship around the world: Implications for family business research and practice. Journal of Family Business Strategy, 10(4), 100249.

Berrone, P., Cruz, C., \& Gomez-Mejia, L. R. (2012). Socioemotional wealth in family firms: Theoretical dimensions, assessment approaches, and agenda for future research. Family Business Review, 25(3), 258-279.

Birley, S., Ng, D., \& Godfrey, A. (1999). The family and the business. Long Range Planning, 32(6), 598-608.

Blumentritt, T. P., Keyt, A. D., \& Astrachan, J. H. (2007). Creating an environment for successful nonfamily CEOs: An exploratory study of good principals. Family Business Review, 20(4), 321-335.

Boland Jr, R. J., \& Tenkasi, R. V. (1995). Perspective making and perspective taking in communities of knowing. Organization science, 6(4), 350-372.

Bourdieu, P. (1986). The forms of capital.

Calabrò, A., Campopiano, G., \& Basco, R. (2017). Principal-principal conflicts and family firm growth: The moderating role of business family identity. Journal of Family Business Management, 7(3), 291-308.

Calabrò, A., Minichilli, A., Amore, M. D., \& Brogi, M. (2018). The courage to choose! Primogeniture and leadership succession in family firms. Strategic Management Journal, 39(7), 2014-2035.

Calabrò, A., Vecchiarini, M., Gast, J., Campopiano, G., De Massis, A., \& Kraus, S. (2019). Innovation in family firms: A systematic literature review and guidance for future research. International Journal of Management Reviews, 21(3), 317-355.

Cesinger, B., Hughes, M., Mensching, H., Bouncken, R., Fredrich, V., \& Kraus, S. (2016). A socioemotional wealth perspective on how collaboration intensity, trust, and international market knowledge affect family Firms' multinationality. Journal of World Business, 51(1), 586-599.

Chrisman, J. J., Chua, J. H., \& Litz, R. (2003). A unified systems perspective of family firm performance: An extension and integration. Journal of Business Venturing, 18(4), 467-472.

Chrisman, J. J., Chua, J. H., \& Litz, R. A. (2004). Comparing the agency costs of family and non-family firms: Conceptual issues and exploratory evidence. Entrepreneurship Theory and Practice, 28(4), 335-354.

Chrisman, J. J., Fang, H., Kotlar, J., \& De Massis, A. (2015). A note on family influence and the adoption of discontinuous technologies in family firms. Journal of Product Innovation Management, 32(3), 384-388.

Classen, N., Carree, M., Van Gils, A., \& Peters, B. (2014). Innovation in family and non-family SMEs: An exploratory analysis. Small Business Economics, 42(3), 595-609.

Coleman, J. S. (1988). Social capital in the creation of human capital. American journal of sociology, 94, S95S120.

Corbetta, G., \& Salvato, C. (2004). Self-serving or self-actualizing? Models of man and agency costs in different types of family firms: A commentary on "comparing the agency costs of family and non-family firms: Conceptual issues and exploratory evidence". Entrepreneurship Theory and Practice, 28(4), 355-362.

Covin, J. G., Eggers, F., Kraus, S., Cheng, C.-F., \& Chang, M.-L. (2016). Marketing-related resources and radical innovativeness in family and non-family firms: A configurational approach. Journal of Business Research, 69(12), 5620-5627.

Craig, J. B., Pohjola, M., Kraus, S., \& Jensen, S. H. (2014). Exploring relationships among Proactiveness, risk-taking and innovation output in family and non-family firms. [article]. Creativity and Innovation Management, 23(2), 199-210.

Cruz, C., \& Nordqvist, M. (2012). Entrepreneurial orientation in family firms: A generational perspective. Small Business Economics, 38(1), 33-49.

De Massis, A., Frattini, F., Pizzurno, E., \& Cassia, L. (2015). Product innovation in family versus nonfamily firms: An exploratory analysis. [article]. Journal of Small Business Management, 53(1), 1-36.

Diéguez-Soto, J., Manzaneque, M., \& Rojo-Ramírez, A. A. (2016). Technological innovation inputs, outputs, and performance: The moderating role of family involvement in management. Family Business Review, 29(3), 327-346.

Dosi, G. (1982). Technological paradigms and technological trajectories. Research Policy, 2(3), I47-I62.

Eddleston, K. A., \& Kellermanns, F. W. (2007). Destructive and productive family relationships: A stewardship theory perspective. Journal of Business Venturing, 22(4), 545-565.

Eddleston, K. A., Kellermanns, F. W., \& Sarathy, R. (2008). Resource configuration in family firms: Linking resources, strategic planning and technological opportunities to performance. Journal of Management Studies, 45(1), 26-50.

Ferreira, J. J. M., Fernandes, C. I., \& Kraus, S. (2019). Entrepreneurship research: Mapping intellectual structures and research trends. [journal article]. Review of Managerial Science, 13(1), 181-205.

Filbeck, G., \& Smith, L. L. (1997). Team building and conflict management: Strategies for family businesses. Family Business Review, 10(4), 339-352.

M Filser, A Brem, J Gast, S Kraus, \& A Calabrò (2016). Innovation in Family Firms: Examining the Inventory and Mapping the Path. International Journal of Innovation Management, (in press), 1650054. 
Misztal, B. (1996). Trust in modern societies.,(Polity Press: Cambridge).

Filser, M., De Massis, A., Gast, J., Kraus, S., \& Niemand, T. (2018). Tracing the roots of innovativeness in family SMEs: The effect of family functionality and socioemotional wealth. Journal of Product Innovation Management, 35(4), 609-628.

Gersick, K. E., Gersick, K. E., Davis, J. A., Hampton, M. M., \& Lansberg, I. (1997). Generation to generation: Life cycles of the family business. Harvard Business Press.

Gómez-Mejía, L. R., Haynes, K. T., Núñez-Nickel, M., Jacobson, K. J., \& Moyano-Fuentes, J. (2007). Socioemotional wealth and business risks in family-controlled firms: Evidence from Spanish olive oil mills. Administrative Science Quarterly, 52(1), 106-137.

Gomez-Mejia, L. R., Cruz, C., Berrone, P., \& De Castro, J. (2011). The bind that ties: Socioemotional wealth preservation in family firms. Academy of Management Annals, 5(1), 653-707.

Grant, R. M. (1996). Toward a knowledge-based theory of the firm. Strategic Management Journal, 17(S2), 109-122.

Habbershon, T. G., \& Williams, M. L. (1999). A resource-based framework for assessing the strategic advantages of family firms. Family Business Review, 12(1), 1-25.

Habbershon, T. G., Williams, M., \& MacMillan, I. C. (2003). A unified systems perspective of family firm performance. Journal of Business Venturing, 18(4), 451-465.

Hadjimanolis, A. (2000). A resource-based view of innovativeness in small firms. Technology analysis \& Strategic management, 12(2), 263-281.

Hall, B. H., Lotti, F., \& Mairesse, J. (2009). Innovation and productivity in SMEs: Empirical evidence for Italy. Small Business Economics, 33(1), 13-33.

Harman, H. H. (1976). Modern factor analysis. University of Chicago Press.

Hatch, N. W., \& Dyer, J. H. (2004). Human capital and learning as a source of sustainable competitive advantage. Strategic Management Journal, 25(12), 1155-1178.

Hitt, M. A., Harrison, J. S., \& Ireland, R. D. (2001). Mergers and acquisitions: A guide to creating value for stakeholders. New York: Oxford University Press.

Hitt, M. A., Lee, H. U., \& Yucel, E. (2002). The importance of social capital to the management of multinational enterprises: Relational networks among Asian and Western firms. Asia Pacific Journal of Management, 19(2-3), 353-372.

Ibarra, H. (1992). Homophily and differential returns: Sex differences in network structure and access in an advertising firm. Administrative science quarterly, 422-447.

Jaffe, D. T., \& Lane, S. H. (2004). Sustaining a family dynasty: Key issues facing complex multigenerational business-and investment-owning families. Family Business Review, 17(1), 81-98.

Jaskiewicz, P., \& Klein, S. (2007). The impact of goal alignment on board composition and board size in family businesses. Journal of Business Research, 60(10), 1080-1089.

Jehn, K. A. (1995). A multimethod examination of the benefits and detriments of intragroup conflict. Administrative Science Quarterly, 256-282.

Jehn, K. A., Northcraft, G. B., \& Neale, M. A. (1999). Why differences make a difference: A field study of diversity, conflict and performance in workgroups. Administrative Science Quarterly, 44(4), 741-763.

Karra, N., Tracey, P., \& Phillips, N. (2006). Altruism and agency in the family firm: Exploring the role of family, kinship, and ethnicity. Entrepreneurship Theory and Practice, 30(6), 861-877.

Kellermanns, F. W., \& Eddleston, K. A. (2004). Feuding families: When conflict does a family firm good. Entrepreneurship Theory and Practice, 28(3), 209-228.

Kellermanns, F. W., \& Eddleston, K. A. (2006). Corporate entrepreneurship in family firms: A family perspective. Entrepreneurship Theory and Practice, 30(6), 809-830.

Kellermanns, F. W., \& Eddleston, K. A. (2007). A family perspective on when conflict benefits family firm performance. Journal of Business Research, 60(10), 1048-1057.

Kor, Y. Y. (2006). Direct and interaction effects of top management team and board compositions on R\&D investment strategy. Strategic Management Journal, 27(11), 1081-1099.

Kor, Y. Y., \& Mahoney, J. T. (2004). Edith Penrose's (1959) contributions to the resource-based view of strategic management. Journal of Management Studies, 41(1), 183-191.

Koskinen, K. U., \& Vanharanta, H. (2002). The role of tacit knowledge in innovation processes of small technology companies. International Journal of Production Economics, 80(1), 57-64.

Kraus, S., Pohjola, M., \& Koponen, A. (2012). Innovation in family firms: An empirical analysis linking organizational and managerial innovation to corporate success. Review of Managerial Science, 6(3), 265-286.

Lane, P. J., \& Lubatkin, M. (1998). Relative absorptive capacity and interorganizational learning. Strategic Management Journal, 19(5), 461-477.

Lansberg, I. (1999). Succeeding generations: Realizing the dream of families in business. Harvard Business Review Press. 
Leana III, C. R., \& Van Buren, H. J. (1999). Organizational social capital and employment practices. Academy of Management Review, 24(3), 538-555.

Llach, J., \& Nordqvist, M. (2010). Innovation in family and non-family businesses: A resource perspective. International Journal of Entrepreneurial Venturing, 2(3-4), 381-399.

Llach, J., Marquès, P., Bikfalvi, A., Simon, A., \& Kraus, S. (2012). The innovativeness of family firms through the economic cycle. Journal of Family Business Management, 2(2), 96-109.

Lubatkin, M. H., Schulze, W. S., Ling, Y., \& Dino, R. N. (2005). The effects of parental altruism on the governance of family-managed firms. Journal of Organizational Behavior: The International Journal of Industrial, Occupational and Organizational Psychology and Behavior, 26(3), 313-330.

Maran, T., Furtner, M., Liegl, S., Kraus, S., \& Sachse, P. (2019). In the eye of a leader: Eye-directed gazing shapes perceptions of leaders' charisma. The Leadership Quarterly, 30(6), 101337.

Miller, D., \& Le Breton-Miller, I. (2005). Managing for the long run: Lessons in competitive advantage from great family businesses. Boston: Harvard Business Press.

Miller, D., Le Breton-Miller, I., \& Scholnick, B. (2008). Stewardship vs. stagnation: An empirical comparison of small family and non-family businesses. Journal of Management Studies, 45(1), 51-78.

Nahapiet, J., \& Ghoshal, S. (1998). Social capital, intellectual capital, and the organizational advantage. Academy of management review, 23(2), 242-266.

Nordqvist, M. (2005). Familiness in top management teams: Commentary on Ensley and Pearson's “an exploratory comparison of the behavioral dynamics of top management teams in family and nonfamily new ventures: Cohesion, conflict, potency, and consensus". Entrepreneurship Theory and Practice, 29(3), 285-291.

Nunnally, J. C. (1967). Psychometric theory. New York: McGraw Hill.

Pearson, A. W., Carr, J. C., \& Shaw, J. C. (2008). Toward a theory of familiness: A social capital perspective. Entrepreneurship Theory and Practice, 32(6), 949-969.

Podsakoff, P. M., MacKenzie, S. B., Lee, J.-Y., \& Podsakoff, N. P. (2003). Common method biases in behavioral research: A critical review of the literature and recommended remedies. Journal of Applied Psychology, 88(5), 879.

Podsakoff, P. M., MacKenzie, S. B., \& Podsakoff, N. P. (2012). Sources of method bias in social science research and recommendations on how to control it. Annual Review of Psychology, 63, 539-569.

Portes, A. (1998). Social capital: Its origins and applications in modern sociology. Annual review of sociology, 24(1), 1-24.

Richard, O. C., Barnett, T., Dwyer, S., \& Chadwick, K. (2004). Cultural diversity in management, firm performance, and the moderating role of entrepreneurial orientation dimensions. Academy of Management Journal, 47(2), 255-266.

Röß1, D., Fink, M., \& Kraus, S. (2010). Are family firms fit for innovation? Towards an agenda for empirical research. International Journal of Entrepreneurial Venturing, 2(3/4), 366-380.

Rothaermel, F. T., \& Hess, A. M. (2007). Building dynamic capabilities: Innovation driven by individual-, firm-, and network-level effects. Organization Science, 18(6), 898-921.

Salvato, C. (2004). Predictors of entrepreneurship in family firms. Journal of Private Equity, 7(3), 68-76.

Salvato, C., \& Melin, L. (2008). Creating value across generations in family-controlled businesses: The role of family social capital. Family Business Review, 21(3), 259-276.

Santulli, R., Torchia, M., Calabrò, A., \& Gallucci, C. (2019). Family ownership concentration and firm internationalization: Integrating principal-principal and socioemotional wealth perspectives. Journal of International Entrepreneurship, 17(2), 220-248.

Schulze, W. S., Lubatkin, M. H., \& Dino, R. N. (2003). Exploring the agency consequences of ownership dispersion among the directors of private family firms. Academy of Management Journal, 46(2), 179-194.

Sirmon, D. G., \& Hitt, M. A. (2003). Managing resources: Linking unique resources, management, and wealth creation in family firms. Entrepreneurship Theory and Practice, 27(4), 339-358.

Sirmon, D. G., Hitt, M. A., \& Ireland, R. D. (2007). Managing firm resources in dynamic environments to create value: Looking inside the black box. Academy of Management Review, 32(1), 273-292.

Sonfield, M. C., \& Lussier, R. N. (2004). First-, second-, and third-generation family firms: A comparison. Family Business Review, 17(3), 189-202.

STEP (2015). Family-Owned Businesses are Determined to Maintain Ownership and Control of Their Companies, According to New Babson Research. http:/www.babson.edu/news-events/babsonnews/Pages/2015-latest-successful-transgenerational-entrepreneurship-practices-step-project-surveyresults.aspx.

Studenmund, A. H. (1992). Using econometrics: A practical guide. New York: Harper Collins.

Thomke, S., \& Kuemmerle, W. (2002). Asset accumulation, interdependence and technological change: Evidence from pharmaceutical drug discovery. Strategic Management Journal, 23(7), 619-635. 
Torchia, M., Rautiainen, M., Calabrò, A., Ikäheimonen, T., Pihkala, T., \& Ikävalko, M. (2018). Family ownership goals and socioemotional wealth: Evidence from Finnish family firms. Journal of Enterprising Culture, 26(02), 207-224.

Tsai, W., \& Ghoshal, S. (1998). Social capital and value creation: The role of intrafirm networks. Academy of management Journal, 41(4), 464-476.

Voordeckers, W., Van Gils, A., \& Van den Heuvel, J. (2007). Board composition in small and medium-sized family firms. Journal of Small Business Management, 45(1), 137-156.

Zahra, S. A. (1995). Corporate entrepreneurship and financial performance: The case of management leveraged buyouts. Journal of Business Venturing, 10(3), 225-247.

Publisher's note Springer Nature remains neutral with regard to jurisdictional claims in published maps and institutional affiliations.

\section{Affiliations}

\section{Andrea Calabrò $^{1}$ - Mariateresa Torchia ${ }^{2}$ - Daniela Gimenez Jimenez ${ }^{3} \cdot$ Sascha Kraus $^{4}$}

1 IPAG Entrepreneurship and Family Business Center, IPAG Business School, 4 bd Carabacel -, 06000 Nice, France

2 International University of Monaco, INSEEC U Research Center, 14 Rue Hubert Clerissi, 98000 Monaco, Monaco

3 TUM School of Management, Technische Universität München, Alte Akademie 14, 85354 Freising, Germany

4 Durham University Business School, Durham University, Mill Hill Lane, Durham DH1 3LB, UK 